\title{
PENGARUH MODEL PEMBELAJARAN PROBING PROMPTING LEARNING TERHADAP HASIL BELAJAR SISWA SMA NURUL AMAL
}

\author{
Ana Theriana \\ DosenUniversitas PGRI Palembang \\ Jalan Gotong Royong Plaju \\ Sur-el: taqiratu@gmail.com
}

\begin{abstract}
The problem in this research was whether there is the effect of the Probing Prompting Learning model on student learning outcomes in the $10^{\text {th }}$ gradersof SMANurulAmal Palembang. The purpose of this study was to determine the influence of Probing Prompting Learning model on student learning outcomes at SMA NurulAmal Palembang. The method used in this study was experimental method using two classes, namely the experimental class and the control class. Meanwhile, the data collection technique was done by tests, and documentation techniques, then the data were analyzed by data analysis technique using t-test analysis. The results showed that the average value of the experimental class was more than 80.24 compared to the control class of 63.6 and the calculations resulted tcountedtableie, $7.02 \geq 1.667$ then Ho was rejected and Ha was accepted. In another words, there was the influence of the Probing Prompting Learning model on learning outcomes.
\end{abstract}

Keywords: Learning Model, Probing Prompting Learning, Learning Outcomes

\begin{abstract}
Abstrak: Permasalahan dalam penelitian ini adalah adakah pengaruh model pembelajaran Probing Prompting Learningterhadap hasil belajar siswa di kelas X SMA NurulAmalPalembang. Tujuan penelitian ini adalah untuk mengetahui pengaruh model pembelajaran Probing Prompting Learning terhadap hasil belajar siswa di SMA Nurul Amal Palembang. Metode yang digunakan dalam penelitian ini adalah metode eksperimen dengan menggunakan dua kelas yaitu kelas eksperimen dan kelas kontrol. Sedangkan teknik pengumpulan data dilakukan dengan tes, dan teknik dokumentasi, kemudian data dianalisis dengan teknis analisis data menggunakan analisis uji-t.Hasil penelitian menunjukkan bahwa dari nilai rata-rata kelas eksperimen lebih besar yaitu 80,24 dari pada kelas kontrol

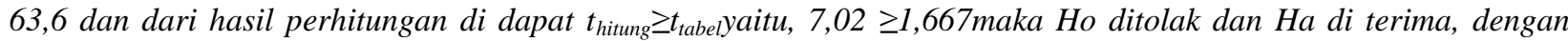
kata lain bahwa ada pengaruh model pembelajaran Probing Prompting Learning terhadap hasil belajar.
\end{abstract}

Kata kunci: Model Pembelajaran,Probing Prompting Learning, Hasil Belajar.

\section{PENDAHULUAN}

Pendidikan adalah proses pembelajaran yang didapat oleh manusia (peserta didik) untuk membantu manusia mengerti, paham, dan mampu membuat manusia lebih kritis dalam berpikir. Pendidikan diperoleh secara formal maupun non formal.Pendidikan tidak hanya didapat dari sekolah tetapi juga didapat dari lingkungan sekitar.Dalam arti sempit pendidikan adalah usaha sadar dan terencana untuk menolong anak didik menjadi matang pendewasaannya.Pendidikan dalam pengertian ini dilakukan oleh institusi formal sekolah.Sedangkan dalam arti luas, semua manipulasi lingkungan yang diarahkan untuk mengadakan perubahan perilaku anak merupakan pendidikan.Dalam pengertian ini 
pendidikan tidak terbatas pada usaha pendewasaan yang dilakukan oleh sekolah tetapi juga oleh keluarga dan lingkungan.

Pendidikan merupakan sebuah proses kegiatan yang disengaja atas input siswa untuk menimbulkan suatu hasil yang diinginkan sesuai tujuan yang ditetapkan (Purwanto, 2016, p. 18). Sementara menurut Hamalik (2015, p. 3), Pendidikan adalah suatu proses dalam rangka mempengaruhi peserta didik supaya mampu menyesuaikan diri sebaik mungkin dengan lingkungannya, dan dengan demikian akan menimbulkan perubahan dalam dirinya yang memungkinkannya untuk berfungsi secara dekat dalam kehidupan masyarakat.

Fungsi pendidikan adalah menyiapkan peserta didik."Menyiapkan" diartikan bahwa peserta didik pada hakikatnya belum siap, tetapi perlu disiapkan dan sedang menyiapkan dirinya sendiri. Hal ini menunjuk pada proses yang berlangsung sebelum peserta didik itu siap untuk terjun ke kancah kehidupan yang nyata. Penyiapan ini dikaitkan dengan kedudukan peserta didik sebagai calon warga negara yang baik, warga bangsa dan calon pembentuk keluarga baru, serta mengemban tugas dan pekerjaan kelak di kemudian hari.

Tujuan pendidikan adalah seperangkat hasil pendidikan yang tercapai oleh peserta didik setelah diselenggarakannya kegiatan pendidikan.Seluruh kegiatan pendidikan, yakni bimbingan pengajaran, dan/atau latihan diarahkan untuk mencapai tujuan pendidikan.Dalam konteks ini, tujuan pendidikan merupakan suatu komponen sistem pendidikan yang menempati kedudukan dan fungsi
sentral.Itu sebabnya, setiap tenaga kependidikan perlu memahami dengan baik tujuan pendidikan, supaya berupaya melaksanakan tugas dan fungsinya untuk mencapai tujuan pendidikan yang telah ditentukan.Sementara menurut Arikunto dalam Purwanto (2016, p. 35), Tujuan pendidikan adalah perubahan prilaku yang diinginkan terjadi setelah siswa belajar.Tujuan pendidikan dapat dijabarkan mulai dari tujuan nasional, institusional, kurikuler sampai instruksional.

Sasaran pendidikan adalah manusia.Pendidikan bermaksud membantu peserta didik untuk menumbuh kembangkan potensi-potensi kemanusiaannya.Potensi kemanusiaan merupakan benih kemungkinan untuk menjadi manusia.Ibarat biji mangga bagaimanapun wujudnya jika ditanami dengan baik, pasti menjadi pohon mangga dan bukannya menjadi pohonjambu (Tirtarahardja, 2008, p. 1).

Ketika melaksanakan kegiatan observasi di SMA Nurul Amal Palembang peneliti diberi kesempatan untuk mengamati proses pembelajaran. Ketika proses KBM berlangsung, guru mengajar dengan menggunakan metode ceramah dalam menyampaikan materi dan pada akhirnya siswa diberi tugas oleh guru. Peneliti melihat kurangnya minat siswa untuk belajar terutama pada mata pelajaran Bahasa Inggris, siswa sering mengantuk dan tidur di dalam kelas pada jam pelajaran berlangsung. Oleh sebab itu guru harus membuat proses KBM menjadi menarik sehingga dapat membuat siswa memperhatikan penjelasan guru ketika sedang melakukan proses KBM. Salah satu caranya ialah dengan menerapkan model-model 
pembelajaran seperti model pembelajaran probing prompting learning sebagai suatu upaya untuk meningkatkan hasil belajar siswa terutama pada mata pelajaran Bahasa Inggris.

Model pembelajaran sangat berguna dalam menyampaikan materi pembelajaran, karena model pembelajaran merupakan suatu rencana atau pola yang digunakan dalam menyusun kurikulum, mengatur materi pelajaran, dan memberi petunjuk kepada pengajar di kelas dalam setting pengajaran ataupun setting lainnya (menurut Dahlan dalam Sutikno, 2014, p. 57). Salah satu upaya untuk meningkatkan hasil belajar siswa adalah dengan menggunakan model pembelajaran Probing Prompting Learning. Menurut Suherman dalam Miftahul Huda (2014, p. 281), Pembelajaran Probing Prompting Learning adalah pembelajaran dengan menyajikan serangkaian pertanyaan yang sifatnya menuntun dan menggali gagasan siswa sehingga dapat melejitkan proses berfikir yang mampu mengaitkan pengetahuan dan pengalaman siswa dengan pengetahuan baru yang sedang dipelajari. Selanjutnya, siswa mengonstruksi konsep-prinsip dan aturan menjadi pengetahuan baru, dan dengan demikian pengetahuan baru tidak diberitahukan.Model pembelajaran Probing Prompting Learning sangat erat kaitannya dengan pertanyaan (Siswanto, 2016, p. 43). Selain itu model pembelajaran probing prompting learning memiliki keunggulan, yaitu siswa aktif berpikir.

Berdasarkan latar belakang masalah di atas, maka peneliti tertarik untuk melakukan penelitian tersebut dengan judul "Pengaruh
Model Probing Prompting Learning terhadap Hasil Belajar Siswa pada Mata Pelajaran Bahasa inggris di Kelas $X$ SMA NurulAmal Palembang.",

Adapun tujuan penelitian ini adalah untuk mengetahui ada tidaknya pengaruh model pembelajaranProbing Prompting Learning terhadap hasil belajar siswa pada matapelajaran BahasaInggris di kelas X SMA NurulAmal Palembang.

Agar penelitilebihterarah dan tidak menyimpang dari tujuan penelitian, maka peneliti membatasi ruang lingkup dari permasalahan ini, yaitu: (1) Model pembelajaran yang digunakan dalam menyampaikan materi pembelajaran adalah model pembelajaran Probing Prompting Learning;

Sampeldalampenelitianini adalah kelas X IPS 2 yang berjumlah 36 siswa sebagai kelas kontrol dan kelas X IPS 4 yang berjumlah 35 siswa sebagai kelas eksperimen; dan (3) Hasil belajar yang dimaksud dari penelitian ini adalah nilai yang diperoleh dari tes berbentuk pilihan ganda sebanyak 20 soal.

\section{METODOLOGI PENELITIAN}

Belajar merupakan proses dalam diri individu yang berinteraksi dengan lingkungan untuk mendapatkan perubahan dalam prilakunya. Belajar adalah aktivitas mental/psikis yang berlangsung dalam interaksi aktif dengan lingkungan yang menghasilkan perubahanperubahan dalam pengetahuan, keterampilan dan 
sikap.Perubahan itu diperoleh melalui usaha (bukan karena kematangan), menetap dalam waktu yang relatif lama dan merupakan hasil pengalaman (Purwanto, 2016, p. 39).

Dari uraian di atas, maka dapat disimpulkan bahwa belajar adalah suatu proses interaksi yang dilakukan oleh seseorang dengan lingkungannya yang ditandai dengan adanya perubahan prilaku/tingkah laku manusia ke arah yang lebih baik.

\subsection{Pengertian Model Pembelajaran}

Menurut Dahlan dalam Sutikno (2014, p. 57) model pembelajaran merupakan suatu rencana atau pola yang digunakan dalam menyusun kurikulum, mengatur materi pelajaran, dan memberi petunjuk kepada pengajar di kelas dalam setting pengajaran ataupun setting lainnya.Sementara Chauhan dalam Hamdayama (2016, p. 128), menyebutkan bahwa model pembelajaran adalah sebuah perencanaan pengajaran yang menggambarkan proses yang ditempuh pada proses belajar mengajar agar dicapai perubahan spesifik pada perilaku siswa seperti yang diharapkan.

\subsection{Pengertian Model Pembelajaran Probing Prompting Learning}

Menurut Siswanto dan Ariani (2016, p. 43), Model pembelajaran Probing Prompting sangat erat kaitannya dengan pertanyaan. Pertanyaanpertanyaan yang dilontarkan pada saat pembelajaran ini disebut Probing question.
Probing question adalah pertanyaan yang bersifat menggali untuk mendapatkan jawaban lebih lanjut dari siswa yang dimaksudkan untuk mengembangkan kualitas jawaban, sehingga jawaban berikutnya lebih jelas, akurat serta beralasan.

Sementara menurut Suherman dalam jurnal Hidayatullah (2014), yang menjelaskan bahwa Probing prompting merupakan suatu model pembelajaran yang mendorong terjadinya proses berpikir sehingga mampu mengaktifkan siswa dan memperoleh pengalaman baru dalam proses pembelajaran. Dengan pengetahuan baru yang didapat selama proses pembelajaran, siswa mampu mengorganisasikan ide-ide mereka dalam diskusi pemecahan masalah. Kegiatan tersebut membuat siswa memikirkan kembali konsep yang dipelajari dan mendalami pengetahuan yang diperoleh, sehingga keterampikan berpikir kritisnya pun dapat terasah.

Teknik probing prompting adalah pembelajaran dengan cara guru menyajikan serangkaian pernyataan yang sifatnya menuntun dan menggali sehingga terjadi proses berpikir yang mengaitkan pengetahuan dan pengalaman siswa dengan pengetahuan baru yang sedang dipelajari. Selanjutnya, siswa mengonstruksi konsep, prinsip, dan aturan menjadi pengetahuan baru.Dengan demikian, pengetahuan baru tidak diberitahukan.

Dengan model pembelajaran ini, proses tanya jawab dilakukan dengan menunjuk siswa secara acak sehingga setiap siswa mau tidak mau harus berpartisipasi aktif, siswa tidak bisa menghindar dari proses belajar mengajar, setiap 
saat ia bisa dilibatkan dalam proses tanya jawab. Kemungkinan akan terjadi suasana tegang, tetapi bisa dibiasakan. Untuk mengurangi kondisi tegang, guru hendaknya mengajukan serangkaian pertanyaan disertai dengan wajah ramah, suara menyejukkan, dan nada lembut.Ada canda, senyum, dan tertawa sehingga suasana menjadi nyaman, menyenangkan, dan ceria.Jangan lupa, jawaban siswa yang salah harus dihargai karena salah adalah ciri bahwa dia sedang belajar dan telahberpartisipasi (Shoimin, 2014, p. 126).

Dari uraian di atas, maka dapat disimpulkan bahwa pembelajaran probing promptinglearning adalah pembelajaran yang sangat erat kaitannya dengan pertanyaan, guru menyajikan serangkaian pertanyaan yang sifatnya menuntun dan menggali sehingga menjadi proses berfikir yang mengaitkan pengetahuan dan pengalaman siswa dengan pengetahuan baru. Selanjutnya siswa dituntut untuk berpikir dalam proses tanya jawab.

\subsection{Kelebihan dan Kekurangan Model Pembelajaran Probing Prompting Learning}

Kelebihan dari Model Pembelajaran Probing Prompting Lerning menurut (Wahyudi Dewi, 2016, p.43) adalahsebagaiberikut:

a. Mendorong siswa berpikir aktif.

b. Memberi kesempatan kepada siswa untuk menanyakan hal-hal yang kurang jelas sehingga guru dapat menjelaskan kembali. c. Perbedaan pendapat antara siswa dapat dikompromikan atau diarahkan pada suatu diskusi.

d. Pertanyaan dapat menarik dan memusatkan perhatian siswa, sekalipun ketika itu siswa sedang ribut, yang mengantuk kembali tegar dan hilang ngantuknya.

e. Mengembangkan keberanian dan keterampilan siswa dalam menjawab dan mengemukakan pendapat.

f. Sebagai cara meninjau kembali (review) bahwa pelajaran yang lampau.

Adapun kekurangan dari Model Pembelajaran Probing Prompting Learning menurut (Wahyudi \& Dewi, 2016:43-44) adalah sebagai berikut:

a. Siswa merasa takut, apalagi bila guru kurang dapat mendorong siswa untuk berani dengan menciptakan suasana yang tidak tegang melainkan akrab.

b. Tidak mudah membuat pertanyaan yang sesuai dengan tingkat berpikir dan mudah dipahami siswa.

c. Waktu sering banyak terbuang apabila siswa tidak dapat menjawab pertanyaan sampai dua, atau tiga orang.

d. Jumlah siswa yang banyak sehingga tidak mungkin cukup waktu untuk memberikan pertanyaan kepada setiap siswa.

e. Dapat menghambat cara berpikir anak bila tidak atau kurang pandai membawakan, misalnya guru meminta siswanya menjawab persis seperti yang ia kehendaki, kalau tidak dinilai salah. 


\subsection{Langkah-langkah Model Pembelajaran Probing Prompting Learning}

Adapun Miftahul menyebutkan bahwa langkah-langkah pembelajaran probing prompting learning yaitu:

a. Guru menghadapkan siswa pada situasi baru, misalnya dengan memperhatikan gambar, rumus atau situasi lainnya yang mengandung permasalahan.

b. Menunggu beberapa saat untuk memberikan kesempatan kepada siswa untuk merumuskan permasalahan.

c. Guru mengajukan persoalan kepada siswa yang sesuai dengan tujuan pembelajaran khusus (TKP) atau indikator kepada seluruh siswa.

d. Menunggu beberapa saat untuk memberikan kesempatan kepada siswa untuk merumuskan jawaban atau melakukan diskusi kecil.

e. Menunjuk salah satu siswa untuk menjawab pertanyaan.

f. Jika jawabannya tepat, guru meminta tanggapan kepada siswa lain tentang jawaban tersebut untuk menyakinkan bahwa seluruh siswa terlibat dalam kegiatan yang sedang berlangsung. Namun, jika siswa tersebut mengalami kemacetan jawaban, dalam hal ini jawaban yang diberikan kurang tepat, tidak tepat, atau diam, guru mengajukan pertanyaan-pertanyaan lain yang jawabannya merupakan petunjuk jalan penyelesaian jawaban. Lalu dilanjutkan dengan pertanyaan yang menuntun siswa berpikir pada tingkat yang lebih tinggi, sampai dapat menjawab pertanyaan sesuai dengan kompetensi dasar atau indikator. Pertanyaan yang dilakukan pada langkah keenam ini sebaiknya dilanjutkan pada beberapa siswa yang berbeda agar seluruh siswa terlibat dalam seluruh kegiatan probing prompting.

g. Guru mengajukan pertanyaan akhir pada siswa yang berbeda untuk lebih menekankan bahwa TKP/indikator tersebut benar-benar telah dipahami oleh seluruh siswa (2014, p. 282-283).

\subsection{Pembelajaran Bahasa inggris di Sekolah Menengah Atas}

Mata pelajaran bahasa Inggris di sekolah pada umumnya terbagi dalam grammar, tenses, writing, listening, dan speaking. Sementara untuk tingkatan universitas, karena dianggap sudah lebih paham, maka mata pelajaran bahasa Inggris dibuat lebih spesifik, dengan hanya memfokuskan pada pengembangan kemampuan conversation, listening dan writing skill saja.Sehingga ketiga unsur tersebut banyak dijadikan sebagai dasar penilaian pada tes bahasa Inggris internasional, seperti TOEIC, TOEFL, IELTS dan lain sebagainya.

Bahasa Inggris pada dasarnya terdiri dari empat macam keterampilan, yaitu Reading, Listening, Speaking dan Writing skills. Keempat komponen tersebutlah yang kita terima dan pelajari di sekolahan serta institusi pelatihan Bahasa Inggris lainnya. Berikut beberapa cara untuk bagaimana meningkatkan keterampilan 
berbahasa Inggris menurut keempat komponen tersebut di atas.

\subsection{Metode Penelitian}

Metode penelitian adalah cara yang digunakan peneliti dalam mengumpulkan datapenelitiannya (Arikunto, 2014 , p. 203) dalam penelitian ini peneliti menggunakan metode eksperimen. Eksperimen adalah suatu teknik cara untuk mencari hubungan sebab akibat antara dua faktor yang disengaja ditimbulkan oleh peneliti dengan mengeliminasi atau mengurangi atau menyisihkan faktor-faktor lain yang mengganggu. Eksperimen selalu dilakukan dengan maksud untuk melihat akibat suatu perlakuan. Sedangkan menurut Sugiyono (2015, p.107), metode eksperimen adalah metode penelitian yang digunakan untuk mencari pengaruh perlakuan tertentu terhadap yang lain dalam kondisi yang terkendalikan.

Dari uraian di atas, maka dapat disimpulkan bahwa metode eksperimen merupakan cara penyajian pelajaran, di mana siswa melakukan percobaan dengan mengalami dan membuktikan sendiri sesuatu yang dipelajari.

\section{Tahap Pengambilan Data}

Tahap ini dimulai dengan memberikan pretest pada kelompok eksperiment dan kelompok kontrol untuk mengetahui kemampuan awal siswa terhadap materi yang akan dipelajari, sebelum dilaksanakannya pembelajaran. Kemudian dilanjutkan dengan memberikan perlakuan berupa proses pembelajaran dengan menggunakan model pembelajaran probing prompting learning sesuai dengan RPP.

Setelah pembelajaran selesai, maka diadakan posttest, untuk mengetahui kemampuan siswa setelah dilakukan kegiatan pembelajaran serta untuk mengetahui perbedaan hasil belajar antara kelompok eksperimen dan kelompok kontrol.

\section{Tahap Penyelesaian}

Pada tahap penyelesaian, peneliti melakukan pengolahan data dan menganalisis data hasil penelitian serta menguji hipotesis penelitian sampai pada penarikan kesimpulan.

\section{Teknik Pengumpulan Data}

Teknik pengumpulan data merupakan langkah yang paling utama dalam penelitian, karena tujuan utama dari penelitian adalah mendapatkan data. Tanpa mengetahui teknik pengumpulan data, maka peneliti tidak akan mendapatkan data yang memenuhi standar data yang ditetapkan (Sugiyono, 2015:308). Dalam penelitian ini penulis menggunakan metode penelitian sebagai berikut:

\section{Dokumentasi}

Dokumentasi adalah menyelidiki bendabenda tertulis seperti buku-buku, majalah, dokumen, peraturan-peraturan, notulen rapat, catatan harian dan sebagainya (Arikunto, 2014,p.201). Dokumentasi digunakan untuk mencari data mengenai hal-hal atau variabel berupa catatan atau dokumen yang dipelajari untuk memperoleh data dalam penelitian.Datadata yang dikumpulkan dengan teknik 
dokumentasi cenderung merupakan data sekunder (Husaini, 2014, p.64).

Dari dua pendapat para ahli di atas, maka dapat disimpulkan dokumentasi adalah pengambilan data yang diperoleh melalui dokumen-dokumen. Dokumentasi digunakan untuk mengambil data berupa denah lokasi penelitian, keadaan sekolah, daftar nama siswa, dandaftarnilaisejarah.

\section{Tes}

Tes adalah serentetan pertanyaan atau latihan atau alat lain yang digunakan untuk mengukur ketrampilan, pengetahuan, intelegensi, kemampuan atau yang dimiliki oleh individu atau kelompok (Arikunto, 2014, p.193). Menurut Purwanto (2016, p.63), Tes merupakan instrumen alat ukur untuk pengumpulan data di mana dalam memberikan respons atas pertanyaan dalam instrument, peserta didorong untuk menunjukkan penampilan maksimalnya.

Tes dalam penelitian ini digunakan peneliti untuk mengetahui kemampuan siswa dalam menguasai materi pembelajaran Bahasa Inggris setelah diterapkan model pembelajaran probing promptinglearning dengan menggunakan tes objektif yaitu soal pilihan ganda sebanyak 20 soal.

\section{TeknikAnalisis Data}

Setelah data terkumpul kemudian dianalisis guna membuktikan hipotesis yang telah dirumuskan untuk selanjutnya dibahas dan disimpulkan. Dalam menganalisis data digunakan beberapa teknik, yaitu :

\section{Uji Normalitas Data}

Uji normalitas data perlu dilakukan untuk mengetahui apakah yang dianalisis normal atau tidak, karena uji t baru dapat digunakan jika data terdistribusi secara normal. Untuk menganalisis data dalam penelitian ini menggunakan uji $\mathrm{t}$ dengan menggunakan rumus sebagai berikut :

a. Rentang (Rank) = Data Terbesar

- Data Terkecil (Supardi, 2016,p.73)

b. Banyak Kelas Interval $\quad=1=3,3 \log n$

c. Panjang Kelas Interval = $\frac{\text { Rentang }}{\text { Banyak Kelas }}$

Untuk langkah selanjutnya adalah :

1) Mencari Distribusi Frekuensi

$$
x=\frac{\sum f_{i X_{i}}}{\sum f_{i}}
$$

\section{Keterangan:}

$\mathrm{x}=$ rata-rata

$\mathrm{X}_{\mathrm{i}}=$ tanda-tanda interval

$\mathrm{f}_{\mathrm{i}}=$ frekuensi yang sesuai dengan tanda kelas interval (Sudjana, 2013:67)

2) Mencari Modus

$\mathrm{Mo}=\mathrm{b}+\mathrm{p}\left[\frac{b 1}{b 1+b 2}\right]$

\section{Keterangan:}

Mo $=$ modus

b = batas bawah kelas modal

$\mathrm{p} \quad$ = panjang kelas modal

$b_{1}=$ frekuensi kelas modal dikurangi frekuensi kelas interval dengan tanda kelas yang lebih kecil sebelum tanda kelas modal

$\mathrm{b}_{2} \quad$ = frekuensi kelas modal dikurangi frekuensi kelas interval dengan tanda kelas yang lebih besar sebelum tanda kelas modal (Sudjana, 2013:77)

3) Mencari simpangan baku/standar deviasi $S^{2}=\frac{n \sum f_{i X i^{2}-\left(\sum f i X i\right)^{2}}}{n(n-1)}$

Keterangan :

$\mathrm{S}^{2} \quad=$ simpangan baku/standar deviasi $\mathrm{f}_{\mathrm{i}}=$ frekuensi yang sesuai dengan tanda kelas interval

$\mathrm{x}_{\mathrm{i}} \quad=$ tanda kelas interval 
$\mathrm{n}=$ banyak data

4) Menguji kenormalan data dengan rumus kemiringan

$K m=\left[\frac{\overline{\mathrm{x}}^{-\mathrm{Mo}}}{\mathrm{s}}\right]$

Keterangan:

$\mathrm{Km}=$ kemiringan

$\bar{X} \quad=$ rata-rata

Mo $=$ modus

S = simpangan baku (Supardi, 2013,p.85)

Data dikatakan model positif jika kemiringan positif dan negatif jika kemiringan negatif dan simetrik jika kemiringan sama dengan nol. Kegunaanujinormalitasadalah untuk mengetahui apakah data yang dianalisis normal atau tidak, jika data berdistribusi normal dapat digunakan alat statistik parametris salah satunya adalah uji t.

\section{Uji Homogenitas Data}

Untuk uji homogenitas dalam penelitian ini peneliti menggunakan uji Bartlett dengan rumus Varians gabungan dari sampel :

$$
\mathrm{S}^{2}=\frac{\left(n_{1}-1\right) S_{1}^{2}+\left(n_{2}-1\right) S_{2}^{2}}{n_{1}+n_{2}-2}
$$

(Sudjana, 2013:208)

1. Nilai Bartlett :

$\mathrm{B}=\left(\log \mathrm{S}_{1}^{2}\right) \sum \mathrm{db}$

2. Uji Bartlett dengan menggunakan statistic Chi Kuadrat :

$\mathrm{X}^{2}=(\mathrm{IN} 10)\left[\mathrm{B}-\sum \mathrm{db} \cdot \log \mathrm{S}_{1}{ }^{2}\right]$

\section{Uji Hipotesis}

Untuk menguji hipotesis ada tidaknya pengaruh yang signfikan model pembelajaran Probing Prompting Learning, maka peneliti menggunakan salah satu teknik analisis data yaitu menggunakan Uji-t, dengan rumus sebagai berikut :

$$
\begin{aligned}
& t=\frac{\bar{X}_{1}-\bar{X}_{2}}{S_{g a b} \sqrt{\left(\frac{1}{n_{1}}+\frac{1}{n_{2}}\right)}} \\
& S_{g a b}^{2}=\frac{\left(n_{e}-1\right) S_{e}^{2}+\left(n_{k}-1\right) S_{k}^{2}}{n_{e}+n_{k}-2}
\end{aligned}
$$

\section{Keterangan:}

$t=$ harga yang menunjukkan standar deviasi

$S_{e}^{2} \quad=$ varians sampel kategori pertama (kelas eksperimen).

$S_{k}^{2} \quad=$ varians sampel kategori kedua (kelas kontrol).

$\overline{X_{1}} \quad=$ nilai rata-rata sampel kategori pertama (kelas eksperimen)

$\overline{X_{2}} \quad=$ nilai rata-rata sampel kategori kedua (kelas kontrol)

$n_{e} \quad=$ jumlah sampel kategori pertama (jumlah kelas eksperimen)

$n_{k} \quad=$ jumlah sampel kategori kedua (jumah kelas kontrol). (Supardi, 2016:329)

\section{Kriteria Pengujian Hipotesis}

Adapun pengujian hipotesis dalam penelitian ini adalah sebagai berikut :

Ha $: \mu_{1}>\mu_{2}:$ Ada pengaruh model pembelajaran probing prompting learningterhadap hasil belajar siswa pada mata pelajaran Bahasa Inggris di kelas X SMA Nurul Amal Palembang.

Ho: $\mu_{1}=\mu_{2}$ : Tidak ada pengaruh model pembelajaran probing prompting learningterhadap hasil belajar siswa pada mata pelajaran Bahasa Inggris di kelas X SMA Nurul Amal Palembang.

Kriteria pengujian hipotesis adalah sebagai berikut :

Terima Ho : Bila t hitung < $\mathrm{t}$ tabel, Ha ditolak Terima Ha : Bila t hitung > $t$ tabel, Ho ditolak 


\section{HASIL PENELITIAN}

Untuk menguji hipotesis data yang diperoleh dari penelitian digunakan analisis statistik. Teknik yang di pakai dalam penelitian ini Uji $t$ digunakan untuk membandingkan hasil belajar rata-rata yang dicapai oleh siswa pada mata pelajaran Bahasa Inggris yang menerapkan model pembelajaran Probing prompting learning maupun yang tidak menerapkan model pembelajaran Probing prompting learning. Untuk melakukan Uji $\mathrm{t}$ diperlukan uji normalitas dan uji homogenitas data, untuk mengetahui merata atau tidaknya penyebaran data. Untuk menganalisis data dilakukan langkah sebagai berikut:

\subsection{Uji Normalitas Data}

Uji normalitas data dilakukan untuk mengetahui apakah data yang akan diolah normal atau tidak. Sebab uji statistik baru bisa digunakan apabila data tersebut terdistribusi normal. Berdasarkan dari daftar distribusi frekuensi maka dapat ditentukan rata-rata $(\mathrm{X})$, simpangan baku $\left(\mathrm{S}^{2}\right)$ dan modus (Mo). Hal ini berkenaan dengan uji statistik parameter $t$ atau uji $t$ yang hanya dapat digunakan bila data yang diperoleh terdistribusi normal.

\subsection{Uji Normalitas Data Kelas Eksperimen}

Setelah proses pembelajaran selesai dilaksanakan maka selanjutnya yang akan dilakukan adalah mengadakan tes hasil $\begin{array}{lllllll}\text { belajar siswa untuk } & \text { kelas } & \mathrm{X} & \text { IPS } & 4\end{array}$ (eksperimen), dan setelah dilakukan tes hasil belajar siswa maka nilainya akan di urutkan

Data nilai tes hasil belajar kelas eksperimen menggunakan model pembelajaran probing prompting learning kemudian disusun dalam daftar distribusi frekuensi dengan langkah-langkah menentukan rentang, banyak kelas, dan panjang kelas yaitu sebagai berikut:

1. $\quad$ Rentang $=$ Nilai terbesar - Nilai terkecil

$$
\begin{aligned}
& =95-50 \\
& =45
\end{aligned}
$$

2. Banyak Kelas $=1+(3,3) \log n$

$$
\begin{aligned}
& =1+(3,3) \log 35 \\
& =6
\end{aligned}
$$

Jadi, banyak kelas yang diambil 6 (enam) kelas

3. Panjang Kelas Interval = $\frac{\text { Rentang }}{\text { Banyak Kelas Interval }}$

$$
=\frac{45}{6}=8
$$

Jadi panjang kelas yang diambil 8 ( delapan)

Selanjutnya nilai siswa tersebut di distribusikan dalam daftar distribusi frekuensi kelas eksperiment dapat dilihat pada tabel IX sebagai berikut:

\begin{tabular}{|c|c|c|c|c|c|c|}
\hline No & $\begin{array}{c}\text { Kelas } \\
\text { Interval }\end{array}$ & Fi & Xi & Fi.Xi & Xi $^{2}$ & Fi.Xi $^{2}$ \\
\hline 1 & $50-57$ & 3 & 53,5 & 160,5 & 2862,25 & 8586,75 \\
\hline 2 & $58-65$ & 1 & 61,5 & 61,5 & 3782,25 & 3782,25 \\
\hline
\end{tabular}




\begin{tabular}{|c|c|c|c|c|c|c|}
\hline & $66-73$ & 2 & 69,5 & 139 & 4830,25 & 9660,5 \\
\hline & $74-81$ & 14 & 77,5 & 1085 & 6006,25 & 84087,5 \\
\hline 5 & $82-89$ & 5 & 85,5 & 427,5 & 7310,25 & 36551,25 \\
\hline & $90-97$ & 10 & 93,5 & 935 & 8742,25 & 87422,5 \\
\hline & & $\begin{array}{c}\mathrm{Fi} \\
= \\
35\end{array}$ & $\begin{array}{c}X \mathbf{X} \\
= \\
\mathbf{4 4 1}\end{array}$ & $\begin{array}{l}\sum \text { Fi.Xi } \\
= \\
2808,5\end{array}$ & $\begin{array}{l}\sum \mathrm{Xi}^{2}= \\
\mathbf{3 3 5 3 3 , 5}\end{array}$ & $\begin{array}{l}\sum_{\mathbf{F i} . X i^{2}}{ }^{230089,75}\end{array}$ \\
\hline
\end{tabular}

Tabel 1. Daftar Distribusi Frekuensi Kelas Eksperimen

Dari tabel X IPS 4 dan distribusi frekuensi hasil belajar siswa kelas eksperimen tersebut dapat dilihat frekuensi nilai dari tiap-tiap kelas interval kelas eksperimen dan nilai tengah dari tiap-tiap interval yang memiliki frekuensi $\left(\mathrm{F}_{\mathrm{x}}\right)$ paling banyak terdapat pada kelas 74-81 sebanyak 14 siswa sedangkan untuk kelas yang memiliki frekuensi terendah terletak pada kelas 58-65 sebanyak 1 orang siswa.

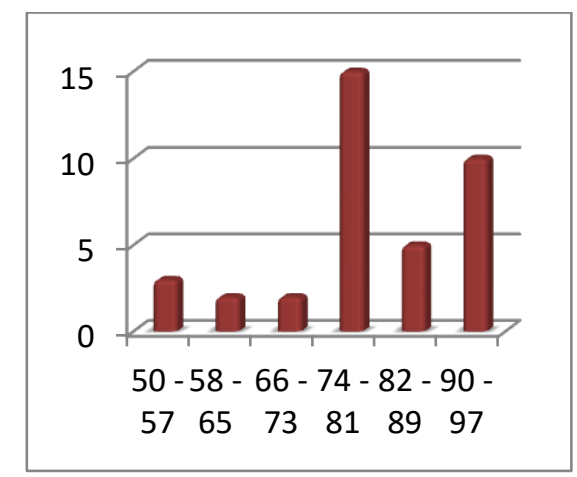

Gambar 1. Diagram distribusi frekuensi hasil belajar kelas eksperimen

4. Nilai rata-rata: $\bar{X}=\frac{\sum f_{i} x_{i}}{\sum f_{i}}$

$$
\begin{aligned}
& \bar{X}=\frac{2808,5}{35} \\
& \bar{X}=80,24
\end{aligned}
$$

Jadi, nilai rata-rata siswa pada kelas eksperimen adalah 80,24 dikategorikan baik.
5. Modus

$$
\begin{aligned}
& \mathrm{b}=74-0,5=73,5 \\
& \mathrm{p}=8 \\
& \mathrm{~b}_{1}=14-2=12 \\
& \mathrm{~b}_{2}=14-5=9 \\
& M_{o}=b+p\left(\frac{b_{1}}{b_{1}+b_{2}}\right) \\
& M_{o}=73,5+8\left(\frac{12}{12+9}\right) \\
& M_{o}=78,06
\end{aligned}
$$

6. Simpangan baku :

$$
\begin{aligned}
S^{2} & =\frac{n \sum f_{i} x_{i}^{2}-\left(\sum f_{i} x_{i}\right)^{2}}{n(n-1)} \\
S^{2} & =\frac{35.230089,75-(2808,5)^{2}}{35(35-1)} \\
S^{2} & =\sqrt{139,04}=11,79
\end{aligned}
$$$$
\text { Jadi nilai varians adalah 11,79 dan }
$$

simpangan baku pada kelas eksperimen adalah 11,79 .

Dari rata-rata, modus dan simpangan baku maka dapat dicari koefisien kemiringan kurva dengan menggunakan rumus Karl Pearson, yaitu :

$$
\begin{aligned}
K m & =\frac{\bar{x}-M o}{S} \\
K m & =\frac{80,24-78,06}{11,79} \\
K m & =0,18
\end{aligned}
$$

Data terdistribusi normal karena $K m=0,18$ terletak antara $(-1)$ dan $(+1)$, maka data kelas eksperimen dapat dikatakan terdistribusi normal.

\subsection{Uji Normalitas Data Kelas Kontrol}


Setelah proses belajar mengajar telah selesai dilaksanakan maka akan dilakukan tes hasil belajar siswa untuk kelas kontrol, untuk lebih jelas mengenai data nilai tes hasil belajar siswa maka dapat dilihat pada tabel X sebagai berikut:

Distribusi frekuensi hasil belajar siswa kelas kontrol tersebut dapat dilihat frekuensi nilai dari tiap-tiap kelas interval kelas kontrol dan nilai tengah dari tiap-tiap interval yang memiliki frekuensi $\left(\mathrm{F}_{\mathrm{x}}\right)$ paling banyak terdapat pada kelas 57-62 sebanyak 10 siswa sedangkan untuk kelas yang memiliki frekuensi terendah terletak pada kelas 51-56 sebanyak 3 orang siswa. Berikut data dalam diagram batang dapat dilihat pada gambar 2 sebagai berikut :

1. Nilai rata-rata: $\bar{X}=\frac{\sum f_{i} x_{i}}{\sum f_{i}}$

$$
\begin{aligned}
& \bar{X}=\frac{2292}{36} \\
& \bar{X}=63,6
\end{aligned}
$$

Jadi, nilai rata-rata siswa pada kelas eksperimen adalah 63,6 dikategorikan kurang baik.

2. Modus

$\mathrm{b}=57-0,5=56,5$

$\mathrm{p}=6$

$\mathrm{b}_{1}=10-3=7$

$\mathrm{b}_{2}=10-5=5$

$M_{o}=b+p\left(\frac{b_{1}}{b_{1}+b_{2}}\right)$

$M_{o}=56,5+6\left(\frac{7}{7+5}\right)$

$M_{o}=60$

3. Simpangan baku :

$$
\begin{aligned}
S^{2} & =\frac{n \sum f_{i} x_{i}^{2}-\left(\sum f_{i} x_{i}\right)^{2}}{n(n-1)} \\
S^{2} & =\frac{36.148539-(2292)^{2}}{36(36-1)} \\
S^{2} & =\sqrt{74,71} \\
S & =8,64 \\
& \text { Dari rata-rata, modus dan simpangan }
\end{aligned}
$$
baku maka dapat dicari koefisien kemiringan kurva dengan menggunakan rumus Karl Pearson, yaitu :

$$
\begin{aligned}
K m & =\frac{\bar{x}-M o}{S} \\
K m & =\frac{63,6-60}{8,64} \\
K m & =0,41
\end{aligned}
$$

Data terdistribusi normal karena $K m_{e}=$ 0,41 terletak antara $(-1)$ dan $(+1)$, maka data kelas kontrol dapat dikatakan terdistribusi normal.

\subsection{Uji Homogenitas Data}

Uji homogenitas data perlu dilakukan untuk membuktikan kesamaan varians kelompok yang membentuk sampel tersebut, dengan kata lain sampel yang diambil berasal dari populasi yang sama. Dengan syarat pengambilan sampel harus representatif artinya merupakan wakil yang baik dari populasi. Untuk menguji hal tersebut digunakan uji Bartlett.

Kemudian dihitung:

Varians gabungan dari semua sampel: 


$$
\begin{aligned}
S_{g a b}^{2} & =\frac{\left(n_{e}-1\right) S_{e}^{2}+\left(n_{K}-1\right) S_{K}^{2}}{\left(n_{e}+n_{K}-2\right)} \\
& =\frac{(35-1) 139+(36-1) 47,64}{35+36-2} \\
S_{g a b}^{2} & =106,35 \\
S_{g a b} & =10,312
\end{aligned}
$$

Harga satuan $\mathrm{B}$ dengan rumus:

$$
\begin{aligned}
B & =\left(\log S_{\text {gab }}^{2}\right) \sum\left(n_{i}-1\right) \\
& =\log (106,35) \times 69 \\
& =139,38
\end{aligned}
$$

Ternyata untuk uji Bartlett digunakan statistik chi kuadrat, dimana $\chi^{2}$ dihitung dengan rumus:

$$
\begin{aligned}
\chi^{2} & =(\ln 10)\left\{B-\sum\left(n_{i}-1\right) \log S_{i}^{2}\right\} \\
& =(2,3026)\{139,38-138,36\} \\
& =2,348
\end{aligned}
$$

Ternyata untuk uji Bartlett $\alpha=5 \%$, dan derajat kebebasan $(\mathrm{db})=\mathrm{k}-1=2-1$ maka, diperoleh $\chi_{\text {tabel }}^{2}=3,841$ sedangkan harga $\chi_{\text {hitung }}^{2}=2,348$ ternyata $\chi_{\text {hitung }}^{2}<\chi_{\text {tabel }}^{2}$ atau $2,348<3,841$

Jika $\chi_{\text {hitung }}^{2}>\chi_{\text {tabel }}^{2}$, tidak homogen

Jika $\chi_{\text {hitung }}^{2}<\chi_{\text {tabel }}^{2}$, homogen

Dari hasil perhitungan di atas disimpulkan bahwa tidak terdapat perbedaan varians diantara kedua sampel tersebut, artinya kelas sampel berasal dari populasi yang sama.

Dari perhitungan di atas, baik kelas eksperimen maupun kelas kontrol mengikuti distribusi normal dan homogen. Oleh karena itu, uji hipotesis yang menggunakan parameter statistik student atau uji t dapat dilakukan.

\subsection{Uji Hipotesis}

Setelah dilakukan pengujian normalitas data dan homogenitas varians, data tersebut dinyatakan berdistribusi normal dan varians dalam penelitian bersifat homogen, maka tahapan selanjutnya yang dilakukan adalah pengujian hipotesis penelitian dengan menggunakan statistik parametris yaitu rumus Uji t:

$$
t=\frac{\overline{X_{1}}-\overline{X_{2}}}{S \sqrt{\frac{1}{n_{1}}+\frac{1}{n_{2}}}}
$$

Dengan, $S_{g a b}^{2}=\frac{\left(n_{1}-1\right) S_{1}^{2}+\left(n_{2}-1\right) S_{2}^{2}}{n_{1}+n_{2}-2}$

Dari perhitungan sebelumnya diperoleh nilai rata-rata data simpangan baku untuk kelas eksperimen dan kelas kontrol dapat dilihat sebagai berikut:

$$
\begin{array}{cc}
S_{1}^{2}=139 & n_{1}=35 \\
S_{2}^{2}=74,64 & n_{2}=36 \\
\overline{X_{2}}=63,6 &
\end{array}
$$

Sehingga:

$$
\begin{aligned}
& S_{g a b}^{2}=\frac{\left(n_{e}-1\right) S_{e}^{2}+\left(n_{K}-1\right) S_{K}^{2}}{\left(n_{e}+n_{K}-2\right)} \\
& =\frac{(35-1) 139+(36-1) 74,64}{35+36-2} \\
& S_{g a b}^{2}=106,35 \\
& S_{g a b}=10,312
\end{aligned}
$$

Maka: 


$$
\begin{aligned}
& t=\frac{\overline{X_{1}}-\overline{X_{2}}}{S \sqrt{\frac{1}{n_{1}}+\frac{1}{n_{2}}}} \\
& t=\frac{80,24-63,6}{10,312 \sqrt{\frac{1}{35}+\frac{1}{36}}} \\
& t=7,02
\end{aligned}
$$

Untuk mencari $t_{\text {tabel }}$ untuk $t(1-a)$

$$
\begin{aligned}
& d k=n_{1}+n_{2}-2 \\
& d k=35+36-2 \\
& d k=69
\end{aligned}
$$

Berdasarkan perhitungan di atas diperoleh $t_{\text {hitung }}$ sebesar 7,02 sedangkan $t_{\text {tabel }}$ adalah nilai $t_{(0,95)(69)}$ yang terdapat pada daftar distribusi $\mathrm{t}$ adalah 1,667. Sehingga $t_{\text {hitung }}$ yang besarnya 7,02 lebih besar dari pada $t_{\text {tabel }}$ yang besarnya 1,667. Dengan demikian, sesuai dengan kriteria pengujian hipotesis yang telah dirumuskan yaitu tolak Ho jika $t_{\text {hitung }}>t_{(1-\alpha)}$ dengan $\mathrm{dk}=$ $n_{1}+n_{2}-2$ dan peluang $(1-\alpha)$.

Dengan demikian maka dalam penelitian ini Ha diterima dan Ho ditolak, sehingga ada pengaruh positif yang signifikan model pembelajaran probing prompting learning terhadap hasil belajar siswa pada mata pelajaran Bahasa Inggris di kelas X SMA Nurul Amal Palembang.

Hal ini terlihat jelas pada nilai rata-rata hasil tes, dimana pada kelas yang menggunakan model probing prompting learning nilai rata-rata hasil tesnya adalah $\overline{X_{1}}=80,24$ sedangkan pada kelas yang tidak menggunakan pembelajaran model pembelajaran probing prompting learning nilai rata-rata hasil tesnya adalah $\overline{X_{2}}=63,6$ dari analisis diperoleh $t_{\text {hitung }}=7,02$ dan $t_{\text {tabel }}$ $=1,667$ dengan $\mathrm{dk}=69$ dan $\alpha=5 \%$.

Sesuai dengan kriteria pengujian hipotesis yang telah dirumuskan yaitu tolak Ho jika $t_{\text {hitung }}>t_{(1-\alpha)}$ dengan $\mathrm{dk}=$ $n_{1}+n_{2}-2$ dan peluang $(1-\alpha)$, maka nilai $t_{\text {hitung }}>t_{\text {tabel }}$ yaitu 7,02>1,667 yang artinya penggunaan model pembelajaran probing prompting learning mempunyai pengaruh positif yang signifikan terhadap hasil belajar siswa.

Dengan demikian hal ini sesuai dengan hipotesis penelitian yang telah dikemukakan bahwa ada pengaruh model pembelajaran probing prompting learning terhadap hasil belajar siswa pada mata Bahasa Inggris di kelas X SMA Nurul Amal Palembang.

\section{KESIMPULAN}

Berdasarkan hasil penelitian dan pembahasan yang telah dilakukan, maka dapat ditarik kesimpulan, bahwa pembelajaran Bahasa Inggris dengan menggunakan model pembelajaran probing prompting learning dapat meningkatkan hasil belajar siswa di kelas $\mathrm{X}$ SMA Nurul Amal Palembang. Hal ini dapat dilihat dengan meningkatnya nilai rata-rata hasil belajar siswa, pada hasil tes akhir siswa. 
Berdasarkan hasil analisis tes menunjukkan adanya pengaruh yang signifikan model pembelajaran probing prompting learning terhadap hasil belajar siswa pada mata pelajaran Bahasa Inggris yang ditunjukkan dengan koefisien $t_{\text {hitung }}$ sebesar 7,02 atau lebih besar dari koefisien $t_{\text {tabel }}$ sebesar 1,667. Rata-rata hasil tes siswa kelompok eksperimen atau yang dikenai perlakuan model pembelajaran probing prompting learning pada mata pelajaran Bahasa Inggris lebih besar dibandingkan dengan ratarata hasil tes siswa kelompok kontrol dengan menggunakan metode ceramah pada mata pelajaran Bahasa Inggris.Maka, Ho ditolak dan Ha diterima.

\section{DAFTAR RUJUKAN}

Arikunto, Suharsimi. 2014. Prosedur Penelitian Suatu Pendekatan Praktik. Jakarta: RinekaCipta.

Hamalik, Oemar. 2015. Kurikulum dan Pembelajaran. Jakarta: BumiAksara.

Hamdayama, Jumanta. 2016. Metodologi Pengajaran. Jakarta: Bumi Aksara.

Hidayatullah, Al Arif, dkk. 2014. PengaruhModel Probing - Prompting Terhadap Kemampuan Berfikir Kritis Siswa Pada Mata Pelajaran IPA Kelas $V$. Bali: Jurnal MIMBAR PGSD Universitas Pendidikan Ganesha. Vol. 2, No. 1 Tahun 2014.

Huda, Miftahul. 2014. Model - Model Pengajaran Dan Pembelajaran. Yogyakarta: PUSTAKA PELAJAR.
Purwanto. 2016. Evaluasi Hasil Belajar. Yogyakarta: Pustaka Belajar.

Shoimin, Aris. 2014. 68 Model Pembelajaran Inovatif dalam Kurikulum 2013. Yogyakarta: Ar-Ruzz Media.

Siswanto, Wahyudi dan Dewi Ariani. 2016. Model Pembelejaran Menulis Cerita. Bandung: Refika Aditama.

Sudjana, 2009. Metode Statiska. Bandung: Tarsito.

Sugiyono. 2015. Metode Penelitian Pendidikan Pendekatan Kuantitatif, Kualitatif dan $R \& D$. Bandung: ALFABETA.

Supardi. 2013. Aplikasi Statistik dalam Penelitian. Jakarta: Smart.

Sutikno, M. Sobry. 2014. Metode \& ModelModel Pembelajaran. Bandung: Buku Kita.

Tirtarahardja, Umar dan La Sulo. 2008. Pengantar Pendidikan. Jakarta: Rineka Cipta. 